\title{
Application of Laminated Veneer Lumber (LVL) on the Wooden Boat Construction
}

\author{
Ahmad Basuki Widodo ${ }^{1}$
}

\begin{abstract}
LVL (Laminated-Veneer Lumber) has many advantages and economic values, which is important for wooden boat construction. The recovery of veneer, the main material of LVL, are higher than sawn-timber and their drying process are faster. LVL produced with a continuous press has been approved as an engineered material with reliable strength and stiffness. In a wooden boat processing, the easy forming into a curve shape and strength are main factor, because of the streamline shape of boats. LVL material is able to meet those requirements. As an endless-length LVL is made from a log limited-length hence LVL always contain joints. Butt joint have numerous drawbacks, but they are inherently simple and less time to manufacture than other joints types. The purposes of this experiment are to investigate the basic characteristics of LVL which are important for deck and hull planking in the wooden boat constructions. Yellow meranti and red meranti were peeled by a veneer lathe and phenol formaldehyde adhesive were used. Result of experiment indicated that at the position $0^{\circ}(\beta)$, the flexibility and strength of LVL up to proportional limit increased with increasing number of layer and spacing of butt-joint $(\mathrm{d} / \mathrm{t})$. LVL at the position $45^{\circ}$ and $90^{\circ}(\beta)$, all types of $\mathrm{LVL}$ had lower flexibility and strength than the standard value for deck and hull planking. In bending experiment test speciment at position $45^{\circ}$ with direction of grain, maximum width of LVL equal to the spacing of frame and at position $90^{\circ}$ equal to the width of hull planking in wooden boat. Based on the interpretations of the above results, it can be concluded that (1). LVL of 9, 6 and 4 plies with upside (inside) veneer butt-joint is appropriate for deck and hull planking in wooden boat manufacturing, (2). LVL of 9, 6 and 4 plies with spacing of butt-joint (d/t) more than 20 is appropriate for deck and hull planking in manufacturing wooden boat.
\end{abstract}

Keywords-LVL, flexibility, strength, hull planking, deck

Abstrak-LVL (Laminated Veneer Lumber) memiliki banyak keunggulan dan mempunyai nilai ekonomi tinggi, yang merupakan factor penting dalam pemilihan bahan untuk konstruksi kapal kayu. Veneer, merupakan bahan utama dalam pembuatan LVL, mempunyai randemen (perbandingan input-output) lebih tinggi dibandingkan dengan kayu gergajian dan proses pengeringan lebih cepat dibandingkan dengan papan kayu. LVL yang diproduksi dengan sistem continous press mememenuhi persyaratan sebagai bahan kapal dan mempunyai elastisitas yang baik. Dalam pembangunan kapal kayu, mudah dibentuk dan kekuatan merupakan faktor utama persyaratan bahan untuk kapal, mengingat bentuk kapal yang streamline. LVL dapat dibuat dengan dimensi yang tidak terbatas dari bahan baku berupa log, maka setiap LVL selalu mengandung sambungan. Sambungan memiliki kelemahan, tetapi dengan penempatan yang tepat pada setiap lapis (layer), maka efek dari sambungan tersebut dapat diminimalkan. Tujuan dari penelitian ini adalah untuk mengetahui karakteristik dasar LVL yang digunakan untuk konstruksi dek dan lambung kapal kayu. Dalam penelitian ini digunakan kayu Meranti Kuning dan Merah Meranti yang dikupas menjadi veneer dan perekat fenol formaldehida digunakan sebagai bahan penggabungan dari beberapa veener tersebut. Dari hasil penelitian menunjukkan bahwa pada posisi $0^{\circ}(\beta)$, fleksibilitas dan kekuatan LVL sampai batas proporsional meningkat dengan meningkatnya jumlah lapisan dan jarak butt-joint $(d / t)$. LVL pada posisi $45^{\circ}$ dan $90^{\circ}(\beta)$, dan untuk jenis LVL ini memiliki fleksibilitas yang lebih rendah dan kekuatan dari nilai standar untuk dek dan papan lambung. Dalam penelitian dan pengujian contoh uji pada posisi $45^{\circ}$ dengan arah serat, lebar maksimum LVL sama dengan jarak frame dan pada posisi $90^{\circ}$ sama dengan lebar lambung papan di kapal kayu. Berdasarkan dari hasil penelitian, dapat disimpulkan bahwa: (1). LVL yang terbuat dari lapisan 9, 6 dan 4 dengan posisi sambungan diatas (dalam percobaan) atau didalam konstruksi kapal, memenuhi persyaratan digunakan untuk dek dan papan lambung pada kapal kayu,(2). LVL dari lapisan 9, 6 dan 4 dengan jarak butt-joint (d/t) lebih dari 20 cocok untuk dek dan lambung papan dalam pembuatan kapal kayu.

Kata Kunci-LVL, fleksibilitas, kekuatan, papan lambung, dek

\section{INTRODUCTION}

$\mathrm{A}_{\mathrm{t}}^{\mathrm{t}}$ t least 65.8 percent of fishermen in Indonesia use traditional boats for catching fish, and about 50 percent of them operate very traditional boats. Effect of using those traditional boats for the exploitation of sea resources (fish) can not be optimum because they can catch fish only at the coast and densely populated areas. In one side, sea in Indonesia is very vast, that is about 60 percent of Indonesia area is covered by sea [1]. In the other side, forest in Indonesia is very vast, that is more than 64 percent of Indonesia land is covered by forest [2] with majority of hardwood species like Dipterocarp. Based on the abundant of above-mentioned resources,

Ahmad Basuki Widodo is with Department of Naval Engineering, Faculty of Engineering and Marine Sciences ,Universitas Hang Tuah, Surabaya, Indonesia. E-mail: abwidodo@yahoo.co.id. come the concept of making wooden boats for exploitation of marine resources (catching fish) from Laminated Veneer Lumber (LVL) as main materials.

Laminated Veneer Lumber (LVL), is one of the most suitable materials for this purposes because it can be processed with higher yield and less time and labor than lumber, glued laminated timber or plywood [3]. Strength of LVL is greater than that of solid wood or laminated wood. LVL manipulation of these defects can permit production of an engineered product having selective and predictable strength properties. All these factors also contribute to a reduction in the variability of strength properties, thus resulting in a more reliable uniform product that can be engineered to meet specific end-use requirements [4].

LVL materials have many advantageous and economic value for wooden boat construction, because LVL is made from rotary peeled veneer it can be 
realized to increase yield from each log [5]. Therefore, wooden boat made from LVL as main material come up to oneself expectations to be inexpensive [6].

Laminated Veneer Lumber, in ship and boatbuilding industry has begun to replace grown timber or crooks, which are sometimes in short supplies. Keels and stems are frequently made from laminated materials, as well as frame, deck-beams and hull planking [7].

There are many marine borer ini tropical waters such as Indonesia [8], hence boats must be treated for protection against to marine boring organisms in manufacturing stage [6]. Using adhesives mixed with preservatives, treatment of LVL is simple and effective [3]. LVL board has been used at shipbuilding yards in manufacturing main structure, that is hull planking, deck, frame, stern, keel and superstructures [9].

In manufacturing wooden boat, easy forming into a curved shape, strength, and length of material are the main factors, because of the streamline shape of the ship [6]. LVL is the materials in which able to meet those requirements.

LVL is expected to have better adaptability to these requirements than lumber or laminated wood. Therefore this study was proposed to investigate the basic characteristics of LVL which are important for deck and hull planking in the wooden boat constructions.

In general, hull planking or shell of wooden boat may be single skin (carvel or clinker), strip, double skin, single skin plieswood or cold moulded laminations. Butts of the out side planking are to be spaced not less than 1.2 meter apart and no butts are to be in the same frame space unless there are three strakes between. Butts joint in the planking are to be strapped or scarphed [10].

Laminated decks are to be glued or bedded to the beams and at the decks edges. They also to be fastened to the beams and the edges by screws or barbed nails. The fastening in seams and butts joint landing on structural members are to be as requirement for deck edges [10].

Laminated Veneer Lumber (LVL), also known as Parallel Laminated Veneer (PLV), is one of the most suitable materials for this purposes because it can be processed with higher yield and less time and labor than lumber, glued laminated timber or plieswood $[3,11]$.

Strength of LVL is greater than that of solid wood or laminated wood. LVL produced with continuous press has been approved as an engineered material with reliable strength and stiffness. In addition, the continuous process produces a product having unlimited length [5]. LVL possesses several advantages not inherent in solid-sawn material. Natural defects such as knots, slope of grain, etc., common in lumber, are dispersed among many layers of veneer, thereby minimizing their effect on strength. Manipulation of these defects can permit production of an engineered product having selective and predictable strength properties. All these factors also contribute to a reduction in the variability of strength properties, thus resulting in a more reliable uniform product that can be engineered to meet specific end-use requirements [4].

LVL materials have many advantage and economic values for wooden boat construction. Because LVL is made from rotary peeled veneer it can be realized to increase yield from each $\log$ [12]. Therefore wooden boat made from LVL as main material come up to oneself expectations to be inexpensive [6].

Deck and hull planking are the main structures in the wooden boat manufacturing because they are integral parts of the ship body. Machines, cargo and important equipment of the ship depend on the body, therefore those section should be paid attention more than other parts [6].

Figure 1 shows the schematic view of wooden boat constructions in which LVL is the main material. Material for deck and hull planking must be easy to form into a curved shape, highly-strong and long. Curve of deck and hull planking determine the size and type of boat and spacing of frame [6].

As an LVL of endless-length is made from a log of limited-length, a piece of LVL always contain joints. Because the butt- joints of veneer ends are significant defects in LVL, those must be staggered and distributed as evenly as possible. Although butt-joint have numerous drawbacks, they are inherently simple and less time to manufacture than other joint types $[4,13]$.

The structure of wooden boat prefers LVL because of its easy processing, uniform properties, good adaptability to curve with small radius, stability, and better edge appearance [3, 14]. Uniform mechanical properties of LVL, and especially its high allowable stress in tension compared to its weight $[4,15]$ make this material useful for the deck and hull planking of boats combined with other structure steel-pipe [11].

\section{METHOD}

This research was done by specifying the material and set up experimentally.

\section{A. Material}

Requirement to wood for deck and hull planking in the wooden boat construction is easy forming into a curve, strength and lightness [6] Shorea meet those requirements [2]. Therefore in this experiment, veneer from yellow meranti (Shorea spp.) was used and peeled by veneer lathe (Hiyama Iron Works Co Ltd. type WR-480 B, (Figure 2).

Requirements to adhesives for wooden boat construction (marine use) is weatherproof and boilproof (WBP) [6]. For this purpose, phenol formaldehyde adhesives (D-17) with hardener (Hot P-5) and filler (powdered wheat) were used.

\section{B. Preparation of $L V L$}

Thickness of veneer 2,3 and $4.5 \mathrm{~mm}$ to make $300 \times 300 \times 18 \mathrm{~mm} \mathrm{LVL}$ with number of layer of 9,6 and 4 respectively. LVLs used in this experiment are shown in Table 1 and Figure 3.

Moisture Content (MC) of veneer is about 5.0 percents (requirement for phenol formaldehyde). Spread of adhesive is $20 \mathrm{gram} /(30 \times 30) \mathrm{cm}$ (double glue line, DGL). Cold press pressure is $10 \mathrm{kgf} / \mathrm{cm}$ for 10 minutes. Hot press pressure is $10 \mathrm{kgf} / \mathrm{cm}$ for 10 minutes with temperature of $145^{\circ} \mathrm{C}$. After the hot pressing, LVL was conditioned for 20 minutes.

\section{Preparation of Test Specimens}

Due to streamline shape of the boat, a piece of LVL used in deck and hull planking will bears bending stress 
in all direction with respect to the fiber direction. Therefore, in this experiment preparation of test specimen was made in $0^{\circ}, 45^{\circ}$ and $90^{\circ}$ with regard to the direction of grain $(\beta)$. The position of LVL in deck and hull planking and preparation of test speciment can be seen in Figure 4.

\section{Testing Procedures}

The position of veneer butt-joint in deck and hull plankingfor the wooden boat construction become inside and outside (Figure 5). In bending experiment, inside butt-joint is read as upside one, and outside buttjoint as down-side one.

To determine bending strength Universal Testing Machines (UTM) of type UEH-10 (Shimadzu Seisakusho Ltd.) and dial gauge was used. Centre loading bending test with $252 \mathrm{~mm}$ span was performed on $18 \times 18 \times 288 \mathrm{~mm}$ specimens at a loading speed of 2.5 $\mathrm{mm}$ per minutes. Then, deflection curve was measured up to proportional limit of the test speciment [16].

The testing was conducted on the laboratory of Wood Science and Technology, Department of Forestry, Faculty of Agriculture, Tokyo University of Agriculture, Tokyo Japan.

\section{E. Measuring of LVL Flexibility}

The allowable design flexibility of LVL can be estimated with the angle $\alpha$ formed by LVL in bending test. The following equation was used to calculate the value of $\alpha$ :

$$
\alpha=900-\cos ^{-1}\left\{\frac{(4 . s . d . f)}{(4 . d . f)}\right\}
$$

$\alpha$ is the flexibility of LVL up to proportional limit $\left(^{\circ}\right), \mathbf{s}$ is the span of test pieces (mm) and $d f$ is the deflection of LVL up to proportional limit (mm). The method of LVL flexibility measurement can be seen in Figure 6.

\section{F. Data and Analysis}

In this study, each test conducted for three replications and analysis data of Randomized Completed Block Design.

\section{RESUlTS AND DisCUSSION}

\section{A. Flexibility and Strength of LVL at the Position $0^{\circ}$ against the Direction of Grain $\left(\beta=0^{\circ}\right)$}

The relationship between flexibility of LVL up to proportional limit and number of layers and spacings and position of veneer butt-joint at the position $0^{\circ}$ against the direction of grain (parallel to grain) can be seen in Figure 8.

In the wooden boat construction, curved shape at a minimum allowable value $\alpha$ (3.0 degrees) was used as standard for deck and hull planking [6].

Comparing to the flexibility of LVL with down-side veneer butt-joint, that of LVL with upside veneer buttjoint was higher. In the LVL with upside veneer buttjoint, maximum flexibility was 3.54 degrees [9 plies, B2 $(\mathrm{d} / \mathrm{t}=\sim)]$ and minimum flexibility was 2.13 degrees $(6$ plies, B2 $(\mathrm{d} / \mathrm{t}=0))$, and in the LVL with down-side veneer butt-joint, maximum flexibility was 3.26 degrees (6 plies, $\mathrm{B}=0$ ) and minimum flexibility was 1.31 degrees (4 plies, B2 $(\mathrm{d} / \mathrm{t}=0))$. The $\mathrm{LVL}$ with spacing of veneer butt-joint $(\mathrm{d} / \mathrm{t})$ more than 20 and upside veneer butt-joint shows the flexibility of more than 3.0 degree in case of the numbers of layers of 9,6 and 4 plies. All of the LVL with down-side veneer butt-joint have the flexibility lower than the standard flexibility for deck and hull planking, except for the 9 plies LVL without butt-joint and with $\mathrm{d} / \mathrm{t}$ of more than 10 .

The relationship between strength of LVL up to proportional limit and number of layer and spacing and position of veneer butt-joint in the position $0^{\circ}$ against the direction of grain (parallel to grain) can be seen in Figure 9.

Strength of solid wood up to proportional limit is used as standard for deck and hull planking. The strength of yellow meranti (Shorea spp.) up to proportional limit is about $497 \mathrm{kgf} / \mathrm{cm} \mathrm{[1].}$

The strength of LVL of 9,6 and 4 plies with upside veneer butt-joint, except for LVL of B2 $(d / t=0)$ is more than standard value for deck and hull planking. The strength of LVL of 6 and 4 plies with down-side veneer butt-joint shows lower value than that of standard solid wood for deck and hull planking. All of the LVL of 9 plies with downside veneer butt-joint, have strength more than that of standard solid wood for deck and hull planking, except for the LVL with B2 $(\mathrm{d} / \mathrm{t}=0)$.

LVLs of 9, 6 and 4 plies with outside (down-side) veneer butt-joint for all spacing of veneer butt-joint $(\mathrm{d} / \mathrm{t})$ are not allowed to be used for deck and hull planking. Even though LVL of 9 plies with down-side veneer buttjoint have strength more than the standard solid wood for deck and hull planking, it has the flexibility lower than the standard flexibility for deck and hull planking. The other reason why the LVL with outside (down-side) veneer butt-joint is not used for deck and hull planking, is gaps in butt-joint which may allow marine insect to penetrate and attack LVL [1].

Referring to the standard flexibility and strength for deck and hull planking and the possibility of marine borer attack, the LVL of 9, 6 and 4 plies with inside (upside) veneer butt-joint will meet the requirements for deck and hull planking in the wooden boat construction.

\section{B. Flexibility and Strength of LVL at the Position $45^{\circ}$ against the Direction of Grain $\left(\beta=45^{\circ}\right)$}

The relationship between flexibility of LVL up to proportional limit and number of layer and spacing and position of veneer butt-joint at the position $45^{\circ}$ against the direction of grain was are shown in Figure 10. Both LVL with upside and down-side veneer butt-joint of 9 , 6 and 4 plies at the position of $45^{\circ}$ against the direction of grain have the flexibility lower than the standard value for deck and hull planking in all kinds of spacing of veneer butt-joint $(\mathrm{d} / \mathrm{t})$. In this case the maximum flexibility was 2.35 degrees ( 6 plies, $\mathrm{B}=0$ ).

The relationship between strength of LVL up to proportional limit and number of layer and spacing and position of veneer butt-joint at the position $45^{\circ}$ against the direction of grain can be seen in Figure 11. Both LVL with upside and down-side veneer butt-joint of 9 , 6 and 4 plies at the position of $45^{\circ}$ against the direction of grain $(\beta)$ have strength lower than that of standard solid wood for deck and hull planking in all kinds of spacing of veneer buttjoint. Maximum strength of LVL at this position was about $41.19 \mathrm{kgf} / \mathrm{cm}$ (4 plies, $\mathrm{B}=$ $0)$. 
At the position of $45^{\circ}$ against the direction of grain $(\beta)$, the number of layers and spacing of veneer buttjoint have a little effect on the flexibility and strength for both upside and down-side veneer butt-joint. As can be seen in Figures 8 and 9, the line of flexibility and strength of both LVL with upside and down-side veneer buttjoint of 9, 6 and 4 plies at the position of $45^{\circ}$ against the direction of grain have no regular pattern in all kinds of spacing of veneer butt-joint $(\mathrm{d} / \mathrm{t})$, because in those position lathe check of veneer is most effective on flexibility and strength.

Spacing of frame fairly depends on type of the boat. Due to the streamline shape of boat, a LVL in deck and hull planking construction will bear bending stress in all direction with respect to the fiber direction.

The bending test specimens were made in various fiber directions $(\beta)$ with respect to the direction of the test specimen length. Maximum width of LVL in deck and hull planking construction is equal to sin $\hat{a}$ of span, and spacing of frame is equal to $\cos \hat{a}$ of span. Therefore, maximum allowable width of LVL which meet the standard flexibility and strength requirements for deck and hull planking can be estimated by the bending test in various fiber direction.

The bending test of test specimen at position $45^{\circ}$ against the direction of grain, maximum width of LVL is equal to the spacing of frame. At those position, the flexibility and strength are lower than the standard value for deck and hull planking. Therefore, width of LVL equal to the spacing of frame is not appropriate to be used for deck and hull planking.

C. Flexibility and Strength of LVL at the Position $90^{\circ}$ against the Direction of Grain $\left(\beta=90^{\circ}\right)$

LVL at the position of $90^{\circ}$ against the direction of grain (perpendicular to grain) is under the influence of only the number of layer, because direction of veneer butt-joint and test specimen are parallel to each other.

The relationship between flexibility of LVL up to proportional limit and number of layer at the position $90^{\circ}$ against the direction of grain (perpendicular to grain) is shown in Figure 12.

Being similar to the flexibility at position of $45^{\circ}$ against the direction of grain, the flexibility of LVL at position of $90^{\circ}$ against the direction of grain have the value lower than the standard for deck and hull planking. Maximum flexibility of LVL at position of $90^{\circ}$ is about 2.52 degrees ( 9 plies).

The relationship between strength of LVL up to proportional limit and number of layer can be seen in Figure 13. The strength of LVL 9, 6 and 4 plies up to proportional limit at position $90^{\circ}$, have the value lower than the standard solid wood for deck and hull planking. Maximum strength of LVL at that position is about $22.66 \mathrm{kgf} / \mathrm{cm}$ (9 plies) and minimum is $10.79 \mathrm{kgf} / \mathrm{cm}(4$ plies). In perpendicular to grain position, number of layer has a little effect on strength and the most influential factor in this position is veneer lathe check.

Low flexibility and strength in case of position perpendicular to the long axis (i.e. cleavage and shear along the plane parallel to the fiber are easy to occur) is a drawback of LVL. This relates to the lathe checks of veneer created during peeling. However, the average strength increases and the deviation decreases with increasing number of layers. In LVL of 9, 6 and 4 plies (veneer thickness 2,3 , and $4.5 \mathrm{~mm}$, respectively), roughness of veneer surface was $13.17,16.83$ and 18.17 $\mu \mathrm{m}$, and lathe check of veneer was $62.33,64.84$ and $65.84 \%$, respectively.

The bending test speciment at position $90^{\circ}$ against the direction of grain, maximum width of LVL is equal to the width of deck and hull planking. At this position, the flexibility and strength are lower than the standard value for deck and hull planking. Therefore, width of LVL equal to the width of deck and hull planking is not appropriate to be used in wooden boat construction.

\section{CONCLUSION}

Based on the interpretations of the above results, it can be concluded that LVL of 9, 6 and 4 plies with upside veneer butt-joint or inside veneer butt-joint is appropriate for deck and hull planking in wooden boat manufacturing. LVL of 9,6 and 4 plies with spacing of butt-joints (d/t) more than 20 is appropriate for deck and hull planking in manufacturing wooden boat. LVL with width equal to the width of spacing of frame $\left(45^{\circ}\right)$ or equal to the width of deck and hull planking $\left(90^{\circ}\right)$ is not appropriate to be used. Therefore, in wooden boat construction, LVL for deck and hull planking must be narrower than spacing of frame in width.

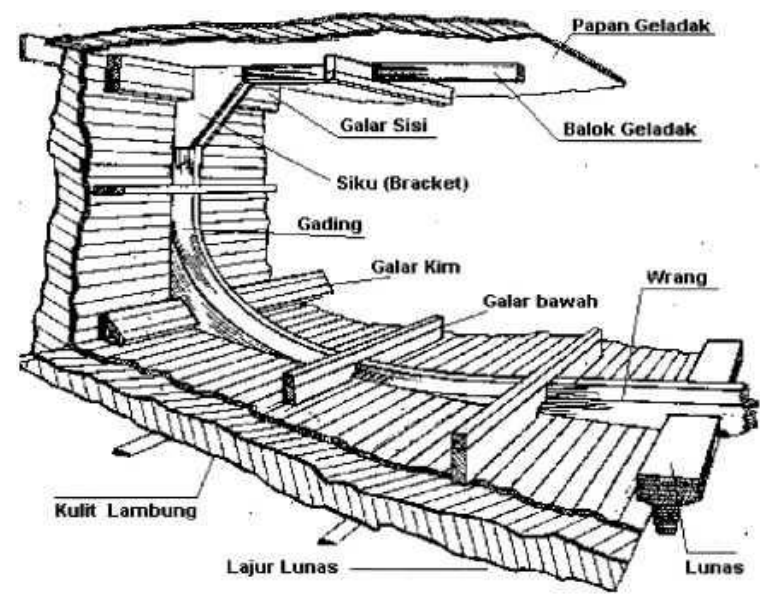

Figure 1. The hull construction of wooden boat [10]

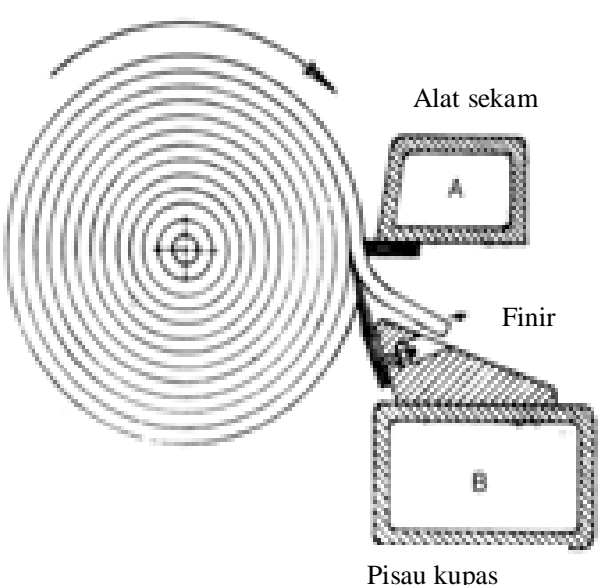

Figure 2. Rotaring veneer cutting [17] 


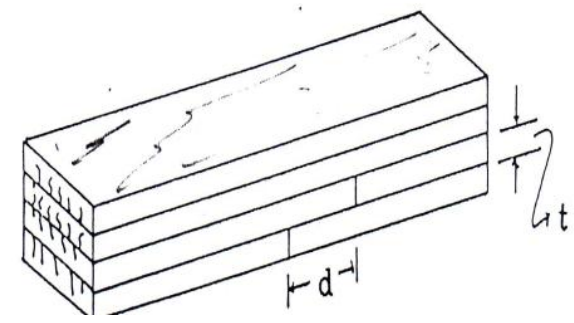

Figure 3. Ilustration of spacing of Veneer butt-joint

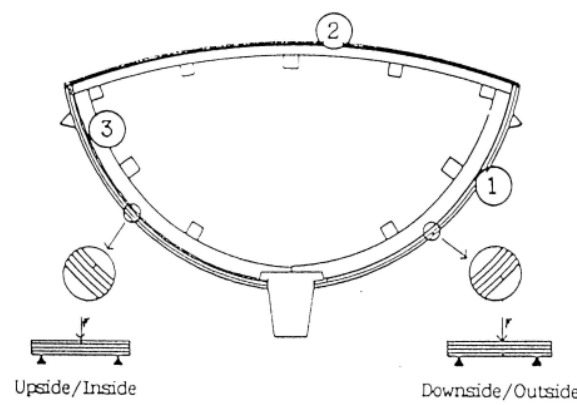

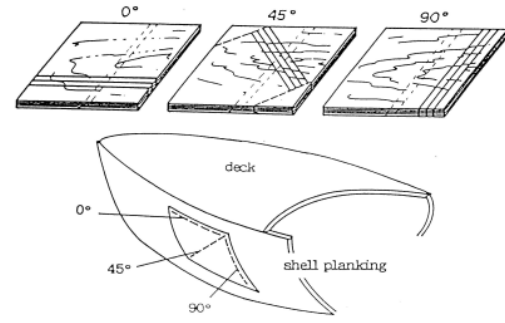

Figure 4. Test speciment models and application of LVL on the wooden boat construction [4]

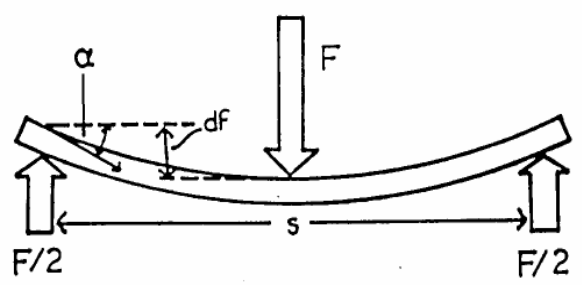

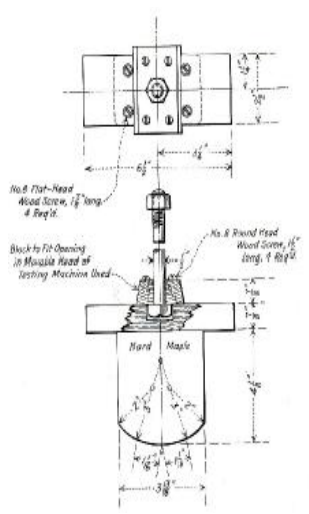

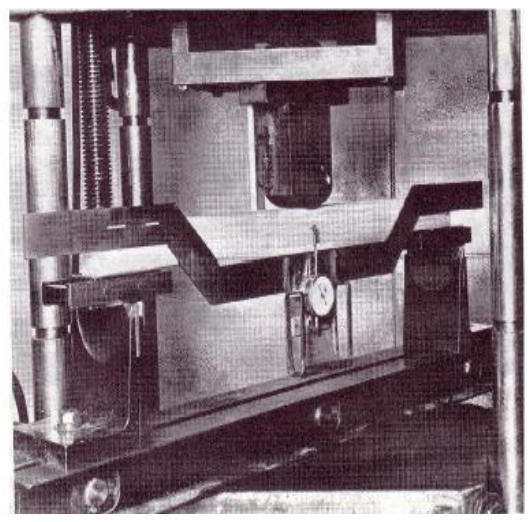

Figure 7. Preparations and testing procedures of LVL

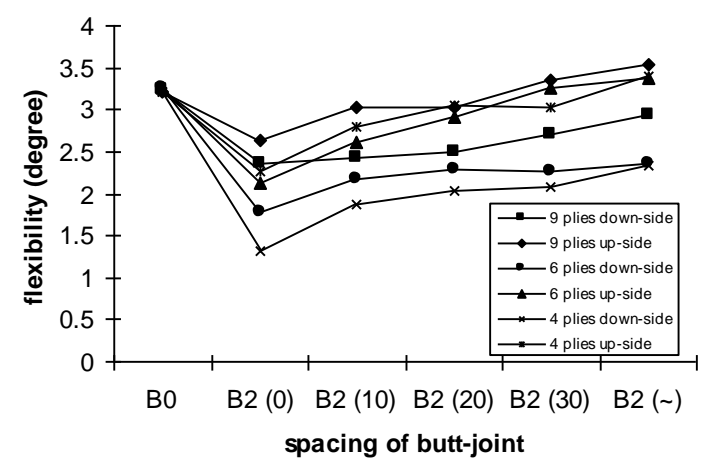

Figure 8. Relationship between flexibility of LVL up to proportional Limit and Number of layers and Spacings and Position of veneer Buttjoint at the Position $0^{\circ}$ against the Direction of Grain (number in the bracket is the value of $d / t$ )

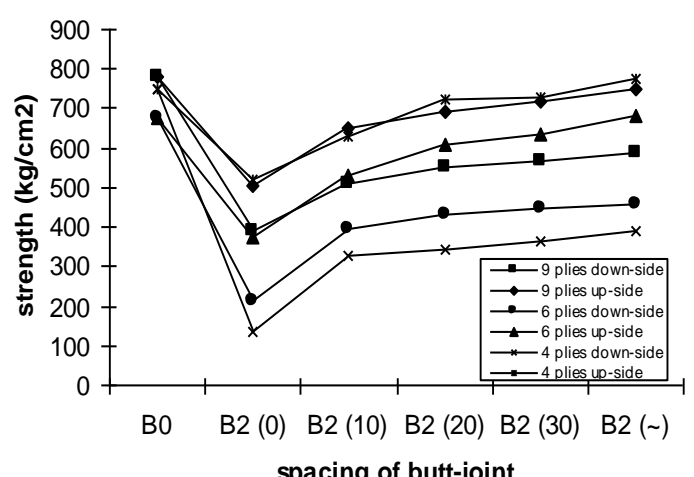

Figure 9. Relationship between strength of LVL up to propotional limit and number of layer and spacing and position of Veneer butt-joint at the position $0^{\circ}$ against the direction of grain (number in the bracket is the value of $d / t$ ) 


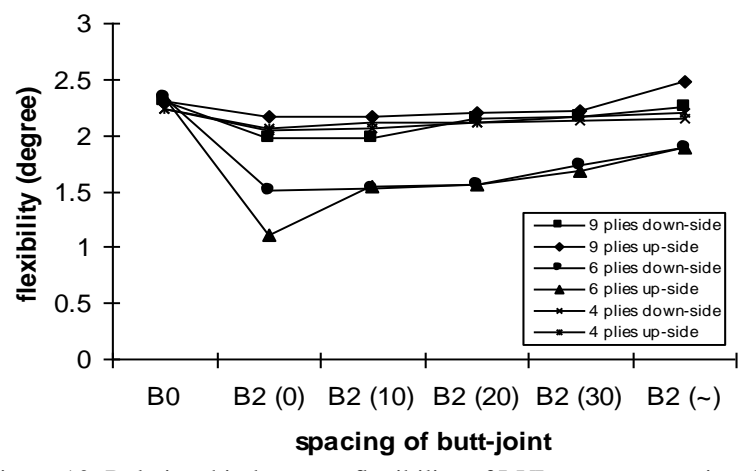

Figure 10. Relationship between flexibility of LVL up to proportional limit and number of layer and spacing and position of Veneer butt-joint at the position $45^{\circ}$ against the direction of grain (number in the bracket is the value of $d / t$ )

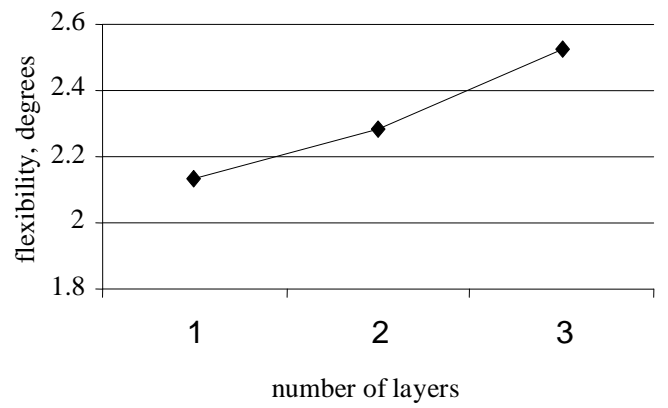

Figure 12. Relationship between flexibility of LVL up to proportional limit and number of layers at the position $90^{\circ}$ against the direction of grain

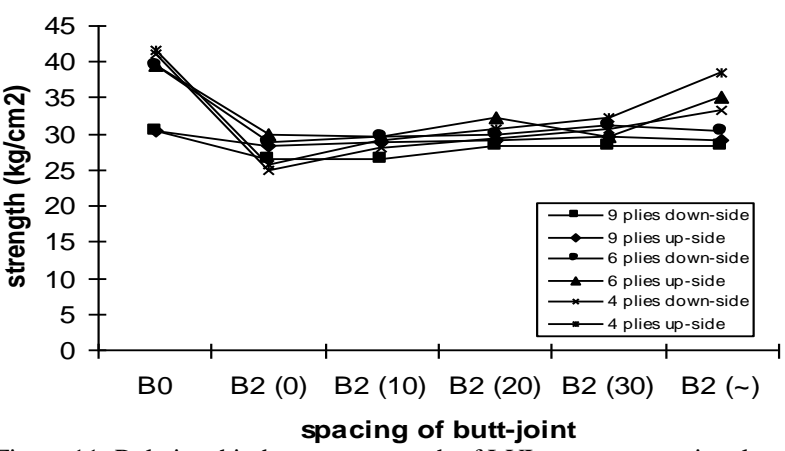

Figure 11. Relationship between strength of LVL up to proportional limit and number of layer and spacing and position of Veneer butt-joint at the position $45^{\circ}$ against the direction of grain (number in the bracket is the value of $d / t$ )

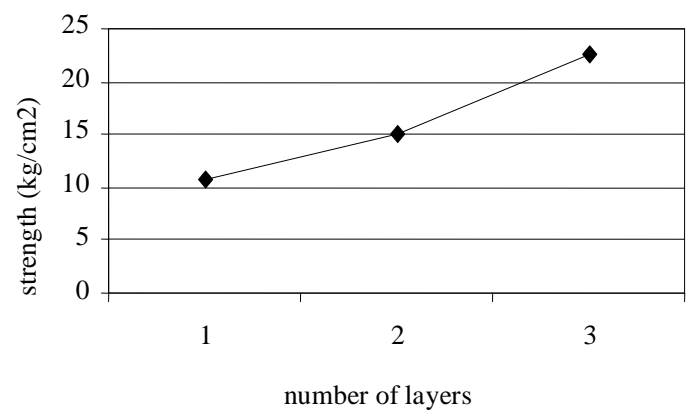

Figure 13. Relationship between strength of LVL up to proportional limit and number of layers at the position $90^{\circ}$ against the direction of grain

TABLE 1 .

SPACING OF VENEER BUTT-JOINT

\begin{tabular}{|c|c|c|c|c|c|c|}
\hline \multirow{3}{*}{\multicolumn{2}{|c|}{ Number of BJ }} & \multirow[t]{3}{*}{$\mathrm{d} / \mathrm{t}$} & \multicolumn{3}{|c|}{$\mathrm{d}(\mathrm{mm})$} & \multirow[t]{3}{*}{ Symbol } \\
\hline & & & \multicolumn{3}{|c|}{ Veneer thickness $(\mathrm{mm})$} & \\
\hline & & & 2 & 3 & 4.5 & \\
\hline$\overline{\bar{\equiv}}$ & 0 & - & - & - & - & B0 \\
\hline$\overline{\overline{\bar{I}}}$ & 2 & 0 & 0 & 0 & 0 & B2 (0) \\
\hline- & 2 & 10 & 20 & 30 & 45 & B2 (10) \\
\hline $\bar{\equiv}$ & 2 & 20 & 40 & 60 & 90 & B2 (20) \\
\hline 1 & 2 & 30 & 60 & 90 & 135 & B2 (30) \\
\hline$\Rightarrow$ & 1 & $\infty$ & $\infty$ & $\infty$ & $\infty$ & $\mathrm{B} 2(\infty)^{*)}$ \\
\hline
\end{tabular}

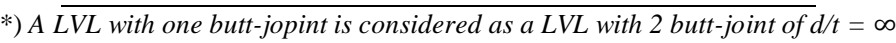

\section{REFERENCES}

[1] Suara Pembaruan (Indonesian Newspaper), (1993, September 14), Tahun VII Num. 2327.

[2] Anonymous, Specification of 60 GT Tuna Long Line (Wooden Construction), Surabaya, PT. PAL Indonesia (Persero), 1992.

[3] A. Martawidjaja, Timber Used for the Shipbuilding Industry in Indonesia, Report No.109, Forest Product Research Institute.Research and Development Departmentof Agriculture. Bogor, 1978.

[4] H. J. Haeruman. "Prosedur Analisa Rancangan Percobaan (Bagian Pertama)", Bagian Perencanaan Hutan, Departemen Manajemen Hutan, Departemen Manajemen Hutan, Fakultas Kehutanan, Institut Pertanian Bogor (IPB), Bogor, 1972.

[5] W. A. Chugg, GLULAM, The Theory and Practice of the Manufacture of Glue Laminated Structures, London: Ernest Been Limited, 1964.
[6] Anonymous, Specification of 60 GT Tuna Long Line (Wooden Construction), Surabaya, PT. PAL Indonesia (Persero), 1992.

[7] A. D. Wood and Thomas Gray-Linn, Plieswood, Their Development, Manufacture and Application, London, UK: W \& AK Johnson Limited, 1950

[8] T. Hayashi, A. Miyata ce, and T. Hashi, Strength Properties of Sugi composite - Glulam II, vol. 38, pp. 247-255, 1999.

[9] W. A. Chugg, GLULAM, The Theory and Practice of the Manufacture of Glue Laminated Structures, London: Ernest Been Limited, 1964.

[10] Anonymous, Rules and Regulations for the Classification of Yachts and Small Craft. Lloyd's Register of Shipping. 71 Fenchruch Street, London, EC3M 4BS, England, 1993.

[11] Anonymous, "Mokuzai Kogyo Handbook", Ringyoshikenjo, Maruzen Kabushiki Kaisha, 1982. 
[12] F. F .P. Kolhmann and Wilferd A. Cote Jr. Solid Wood, Principles of Wood Science and Technology I, George Allen 8 Unwin Ltd, 1968.

[13] J. J. Lee and M. Okuma, Effect of End Joints of Veneer on the Strength of Laminated Veneer Lumber I, Mokuzai Cakicaishi vol. 31 (11), pp. 888-895, 1985.

[14] M. Okuma. Kozoiyo tariparisekizozai ni tsuite (structural of Laminated Veneer Lumber), Mokuzai Kogyo, vol. 29 (9), pp. 373-377, 1979 .
[15] J. J. Lee and M. Okuma, Bending Properties of Laminated Veneer Lumber Made from Domestic Softwood, Mokuzai Kogyo, vol. 39 (5), pp. 221-226, 1976.

[16] American Society for Testing and Materials, "Standard Methods of Testing Veneer, Plieswood, and Other Glued Laminated", Philadelphia, Pa: ASTM D 805-63, 1965.

[17] J. F. Dumanauw. Mengenal Kayu. Semarang: Pendidikan Industri Kayu Atas. 1993. 